\title{
Meaning of Invitation and Prohibition Modality in Quran Translation Texts and Their Connection with Character Education
}

\author{
Markhamah \\ Lecturer of Language Studies Program \\ Post Graduate School, Universitas Muhammadiyah Surakarta \\ Surakarta, Indonesia \\ markhamah@ums.ac.id \\ Atiqa Sabardila \\ Lecturer of Language Studies Program \\ Post Graduate School, Universitas Muhammadiyah Surakarta \\ Surakarta, Indonesia
}

\author{
Febriarni Fatiha Falahallaily Futih \\ Student of Language Studies Program \\ Post Graduate School, Universitas Muhammadiyah Surakarta \\ Surakarta, Indonesia \\ febriarnifutih@gmail.com \\ Abdul Ngalim \\ Lecturer of Language Studies Program \\ Post Graduate School, Universitas Muhammadiyah Surakarta \\ Surakarta, Indonesia
}

\author{
Muhammad Muinuddinillah Basri \\ Lecturer of Language Studies Program \\ Post Graduate School, Universitas Muhammadiyah Surakarta \\ Surakarta, Indonesia
}

\begin{abstract}
This research aims to describe the meaning of invitation and prohibition modality in Quran translation texts and their connection with character education. The subject of this qualitative descriptive study is Quran translation texts containing language ethics. The object of research is the meaning of invitation and prohibition modality adverbial markers and their connection with character education. Data in the forms of adverbial markers for invitation and prohibition modalities were collected from Qur'an Indonesian translation version. The collected data were then analysed to see how the modalities have connection with character values. Research results show that prohibition modality adverbial markers is connected to muamalat (dealings), aqidah (creed), and ibadah (servitude). Connection to muamalat is the highest in frequency, 25 times found. Connection to ibadah is the lowest in frequency, only 2 times found. Character education value is found in connection to those lingual units. In addition to character education values in accordance to character values in Kepmendiknas (2010), 5 other character values are also found: politeness, wisdom, justice, leadership, and love.
\end{abstract}

Keyword-modality; meaning of invitation modality; meaning of prohibition modality; Quran Translation Texts; character value

\section{INTRODUCTION}

Quran is a book muslims must read and apply in life. Thus, Quran is not just texts or ideas, but also a pillar and guideline for muslims. The language of Quran is Arabic, as mentioned in Yusuf 12:1-3.

1) Alif, Lam, Ra. These are the verses of the clear Book.

2) Indeed, We have sent it down as an Arabic Quran that you might understand. 3) We relate to you, [O Muhammad], the best of stories in what $\mathrm{We}$ have revealed to you of this Quran although you were, before it, among the unaware. (Yusuf 12: 1-3).

From the verses, it is clear that the language used by Quran is Arabian. Katsir (2016, p. 532) stated that Arabian is the broadest, clearest, and the right languange to express meaning in one self. Allah also sent Quran in the most noble of months to the most gracious prophet through the most exalted angel and in the most blessed language.

Language is stated as sistematic units (Mahayana, 2008, p. 4), comprised of subsystems of phonology, grammar, lexicon, morphology, and syntax, which altogether covers linguistics. In languages, there are word in the world, including Batak Toba, Javanese, Indonesian, Russian, Japanese, etc. categories that are not always the same in one another. There are differences and also similarities. Some categories that almost all languages have, including Indonesian, are noun, verb, adjective, adverb, etc.

One of the categories in Indonesian language is adverb (Muslich, 2008, p. 119), which traditionally means explanatory words. Researches on adverbs have been carried out in many languages.

The writer is interested instudyingadverbials in Quran translation texts, especially in chapters and verses containing language ethics and focuses the research on modality of invitation and prohibition. In addition, the writer also observed the existence of character values in relationship with the use of the adverbials. The purpose of the research is to describe the meaning of invitation and prohibition modality adverbial markers and their relationship to character education. 


\section{THEORETICAL BACKGROUND}

Ramlan (1991, pp. 52-53) states that adverbial is a category that can accompany adjective, numerals, or preposition in syntactic construction. Commonly, adverbials are in base form; but forms of derivative affixes or confixes are also found (Chaer, 2015, p. 49). Widjono (2012, p. 173) defines adverbial as word that provides information to verb, adjective, noun, predicative, or sentence. In a sentence, adverbial can accompany adjective, numeral, or preposition. In Indonesian language, adverbial is used to explain aspect, modality, quantity, and quality. Modality explains attitude and situation of the speaker that involves action, event, situation, or character (Kridalaksana, 2005, p. 84). Chaer (2011, pp. 171-172) provides examples of modality, such as belum, sedang, akan, boleh, dapat, harus, wajib, mesti, and jangan.

Wirjosoedarmo (1984, p. 186) stated that words that signify modality are: (a) Certainty: memeng, niscaya, pasti, sungguh, sesungguhnya, tentu, sebenarnya, tidak, tidak dapat tidak, (b) Confession: benar, betul, bahkan, malahan, ya, (c) Doubt: agaknya, barangkali, entah, mungkin, rasamnya, rupanya, kiranya, kalau-kalau, gerangan, (d) Desire: moga-moga, mudah-mudahan, (e) Invitation: mari, hendaknya, (f) Obligation: wajib, harus, perlu, (g) Prohibition: jangan, (h) Denial: bukan, bukannya, tidak, dan (i) Disbelief: masakan, mustahil.

Character education is an effort from educators to shape students into human beings with good characters. Ramli (2003) stated that character education has the same meaning with moral and akhlak (mentality) education. Both of the education focuses on value reflected in daily life.

\section{METHOD OF RESEARCH}

Adverbial markers for invitation and prohibition were collected from Quran Indonesian translation version, especially on verses containing language ethics (Sabardilla, et al. 2003). The collected data were then analysed to explain how the modalities might have connection to characters values and education.

\section{RESULTS AND ANALYSIS}

Based on research carried out, 9 invitation modality and 37 prohibition modality are found. Both modality are classified in accordance to the meaning contained within, muamalah, aqidah, and ibadah as follows.

TABLE I. INVITATION AND PROHIBITION MODALITY IN QURAN TRANSLATION TEXTS

\begin{tabular}{|c|c|c|c|c|}
\hline No & Type & Marker & Division & Total \\
\hline \multirow[t]{2}{*}{1} & \multirow[t]{2}{*}{ Invitation } & \multirow[t]{2}{*}{ Hendaknya } & Muamalah & 6 \\
\hline & & & Akidah & 3 \\
\hline \multirow[t]{3}{*}{2} & \multirow[t]{3}{*}{ Prohibition } & \multirow[t]{3}{*}{ Janganlah } & Muamalah & 25 \\
\hline & & & Akidah & 10 \\
\hline & & & Ibadah & 2 \\
\hline
\end{tabular}

\section{A. Invitation modality}

1) Invitation modality in connection with muamalah

Invitation modality adverbial markers hendaklah are found in 6 instances: An-Nisaa' (4:9), Al-Maaidah (5:41), Al-An'aam (6:152), and Al-Israa' (17:23). Muamalah is described as various things related to social interaction and society (Sugono, 2012, p. 931). Tarmizi (2013, p. 1) mentioned that muamalah is about human to human interaction. Invitation modality that is related to muamalah is invitation to build good relationships to the Prophet and general muslims.

Invitations found are: not to leave children in poor condition when you die, An-Nisaa' (4:9). Management of inheritance must prioritize family and expressed in nice words. Al-Maaidah (5:41) contains invitation for the Prophet not to be sad because of disbelievers. Al-An'aam (6:152) invites to be just in any situation and condition. Al-Israa' $(17: 23)$ invites to obey parents and not to break their hearts.

2) Invitation modality in relationship with akidah

Aqidah is the concept of fundamental faith of Islam (Sugono, 2012, p. 27). Invitation modality that has relation to aqidah has something to do with basic faith or the six core principles of faith. Adverbial marker hendaklah is found in 3 instances of texts: An-Nisaa' (4:9), An-Nur (24:63), and AlFath (58:10). An-Nisaa' (4:9) is about invitation to have faith in God. An-Nur (24:63) invites those who do not obey God's command to fear. Invitation to surrender and have faith in God is found on Al-Fath (58:10).

\section{B. Prohibition modality \\ 1) Prohibition modality in relationship with muamalah}

Muamalah is described as various things related to social interaction and society (Sugono, 2012, p. 931). Tarmizi (2013, p. 1) mentioned that muamalah is about human to human interaction. Prohibition modality that connects with muamalah uses adverbial marker jangan, which is found in 13 instances: Al-Baqarah (2:235), An-Nisaa' (4:135), AlMaaidah (5:41 dan101), Al-An'aam (6:108, 151, dan 152), Al-Israa' (17:23), Al-Kahfi (18:23-24), An-Nur (24:53 dan 63), Al-Ahzab (33:32), Yasin (36:76), Sad (38:26), AlHujurat (49:2-3 dan 11), Al Mujadalah (58:9) dan Ad-Duha (93:10).

Al-Baqarah (2:235) forbids marriage with woman in their idah (waiting) period. An-Nisaa' (4:135) prohibits following lust. Al-Maaidah (5:41) disallows the Prohphet being sad because of disbelievers. 5:101 forbids asking questions that bring difficulties. Prohibition of cursing idols of disbelievers is found on Al-An'aam (6:108). Verse 151 of the same chapter mention prohibition of killing children out of fear of poverty. Verse 152 forbids stealing the treasure of orphans. Al-Israa' (17:23) prohibits saying bad words and yelling at parents. Al-Kahfi (18:23-24) prohibits making promises without the name of God.

Prohibition of of swearing is found in An-Nur (24:53). Verse 63 forbids calling the Prophet like a commoner, must use proper title. Al-Ahzab (33:32) suggestswomen from softening their voice. Yasin (36:76) forbids being sad because of what the disbelievers say. Prohibition of leaders making decisions by following lust is found on Sad (38:26). Al-Hujurat (49:2-3) prohibits raising voice and tone in front 
of the Prophet. Al-Hujurat (49:11) forbids mockin and calling using derogatory names. Prohibition of planning bad actions is found on Al-Mujadalah (58:9). Surat Ad-Duha (93:10) forbids harassing poor people.

2) Prohibition modality in relationship with aqidah

Prohibition modality adverbial marker janganlah that relates to aqudah is found in 7 instances: Al-Baqarah (2:42), Ali Imron (3:118), An-Nisaa'(4:5 and 171), Al-An' aam (6:151), Al-Hijr (15:53), An-Nur (24:11), and Asy-Syura (42:15). Aqidah is basic faith or core principle (Sugono, 2012:27), consisting of faith toward Almighty God, angels, books, prophets, end of days, and fate.

Al-Baqarah (2:42) contains prohibition of stealing and hiding the truth. Prohibition of making a close friend of non muslims is found on Ali Imron (3:118). Prohibition of giving treasure to immature person is found on An-Nisaa' (4:5). Verse 171 contains prohibition of breaking religious rules such as lying and denying God. Al-An'aam (6:151) prohibits taking another god but Allah. Surat Al-Hijr (15:53) forbids Ibrahim and Sarah to not fear the angels sent by God. Prohibition of seeing trials as a bad thing is found on An-Nur (24:11). Asy-Syura (42:15) prohibits disbelievers from following lust, worshipping idols, and lying.

3) Prohibition modality in connection with ibadah

Prohibition modality adverbial marker that has relation to ibadah is found on Al-Israa' (17:110). Az-Zuhali (2010, pp. 199-200) defines ibadah as all matters liked and blessed by Almighty God. It is in accordance with five core obligations of Islam: shalat, zakat, puasa, haji, and jihad. Al-Israa' $(17: 110)$ prohibits making voice louder or softer in sholat (daily prayers). The voice of imam (leader of prayers) must not be too loud or too soft.

This research is in line with Rosdawita's findings (2012). The similarity of results are found in the types of adverbials found, which is jan or usah "jangan". Rosdawita also found modality nak "hendak". The difference between the researches are in the classification of results. Rosdawita classsifies the results into original and combination modality markers, in addition of variation of modality adverbials, while this research classifies the results into invitation and prohibition modality.

Cristiana (2008) also carried out adverbial research. The similarity with this research is both focus on the meaning of adverbial. The difference is that Christiana studied Russian adverbials and how the meaning is expressed in Indonesian. Her research is about form, meaning, modifier category, verb adverbial position, and the semantic implications. Meanwhile, this research focuses on meaning of adverbials and their connection to character education.

Similar research was carried out by Khasanah (2015). The similarity with this research is both studies adverbials. The difference lies in the language studied. Khasanah studied Japanese, but this research studies Indonesian.

Another research on adverbials was performed by $\mathrm{Xu}$ (2012). The similarity with this research, both studies adverbials. The difference is in results and focused adverbials. Xu studied the use of conjunction adverbials between EFL China students and native speakers. This research studies meaning of modality adverbials in Quran translation texts.

Kiss (2011) also carried out another adverbial research about syntactic and semantic behavior in adverb constituents in Hungarian. The focus of research is on syntax structure in Hungarian and adverbial modification. Kiss research are different to this research that studies meaning of modality adverbials. This research does not study syntax structure, but the meaning of adverbials. The result of both researches are far different though both studies adverbials.

Other than adverbial researches, there are also researches that studies Quran translation texts just like this research. Shofiyuddin (2013) studied type, process, and rule of transformation in Quran translation texts. Sholichah (2014) studied the use and difference between meaning of lexical cohesion of synonymy in Quran translation texts. Astati (2013) studied the form and factor of linguistic politeness in Quran translation texts. Ramadhana (2014) studied linguistic hierarchy in Quran translation texts. Markhamah (2012) studied type and function of replacement transformation in Quran translation texts.

Other researchers whoalso studied Quran translation texts are Markhamah (2003) focusing on gender in Quran translation texts about male and female, Markhamah and Atiqa (2010) studying coherence of function, category, and role in Quran translation texts, and Markhamah et al (2012) finding the development of teaching and study material of syntax based on Quran translation texts. All those researches have the same object as this reasearch, which is Quran translation texts.

\section{RELATIONSHIP OF ADVERBIAL MEANING AND CHARACTER EDUCATION}

Adverbial meaning can be related toachievement in character education. Character education is seen as effort to improve morality in students. In this research, six character values are found in accordance to Kemendiknas (2010, pp. iii), which are religiousity, tolerance, responsibility, honesty, peace loving, and discipline. Religious values are found in Ali Imron (3:118) (prohibition of making a close friend of non muslims; ukhuwah islamiyah or muslim friendships comes first), An-Nisaa' (4:5) (prohibition of breaking religious rules, such as lying and denying God), An-Nisaa' (4:9) (invitation to belief in God), Al-An'aam (6:151) (prohibition of taking another god), Al-Hijr (15:53) (prohibition of not fearing angels sent by God), Al-Kahfi (18:23-24) (prohibition of making promises without the name of God), An-Nur (24:11) (prohibition of considering trials a bad thing), An-Nur (24:53) (prohibition of making empty promises), An-Nur (24:63) (invitation to those who do not follow orders of God to fear), Asy-Syuara (42:15) (prohibition to disbelievers from following lust such as worshipping idols and lying), dan Al-Fath (58:10) (invitation to believers to surrender to God and have faith).

Tolerance value is found on Al-Maaidah (5:41) (prohibition and invitiation to Muhammad not to be sad because disbelievers), Al-An'aam (6:108) (prohibition of 
cursing disbelievers' idols), dan Yasin (36:76) (prohibition of being sad because of words of disbelievers). Responsibility value is found on An-Nisaa' (4:9) (invitation not to leave children poor) dan An-Nisaa' (4:5) (prohibition of giving treasure to immature person). Honesty value is found on AlBaqarah (2:42) (prohibition of hiding the truth) dan AlAn'am (6:152) (prohibition of stealing the treasures of orphans). Peace loving value is found on Al-Mujadalah (58:9) (prohibition of planning bad things). Discipline value is found on Al-Baqarah (2:235) (prohibition of marrying a girl in iddah or waiting period after divorce).

In addition to the six values stated by Kepmendiknas (2010), there are five character values found: politeness, wisdom, justice, leadership, and love. Politeness value is found in An-Nisaa' (4:9) (saying nice and correct words in management of inheritance), Al-Israa' (17:23) (being nice to parents by obeying their orders and not saying bad words), Al-Israa' (17:110) (prohibition of making voice louder or softer during prayers), An-Nur (24:63) (prohibition of calling the Prophet like a commoner, must use proper title ), AlAhzab (33:32) ) (prohibition of softening voice for women), Al-Hujurat (49:2-3) (prohibition of using loud and high tone in front of the Prophet), dan Al-Hujurat (49:11) (prohibition of mocking, criticizing, and calling using names). Wisdom value is found on Al-Baqarah (2:42) (prohibition of taking what is not yours), An-Nisaa' (4:135) (prohibition of following lust), Al-Maaidah (5:101) (prohibition of asking something that couse difficulty), dan Al-An'am (6:151)(prohibition of murdering child because of fearing poverty). Justice value is found on An-Nisaa' (4:9) (inheritance must prioritize family) dan Al-An'aam (6:152) (invitiation to be just in any situation). Leadership value is found on Sad (38:26) (prohibition of leaders making decisions by following lust). Love value is found on AdDuha (93:10) (prohibition of harassing the poor).

\section{CONCLUSION}

Meaning of invitation and prohibition modality adverbs is classified in accordance to the meaning contained within such adverbs, i.e.muamalah (application), akidah (faith), and ibadah (worship). Invitation adverbial modality marked with hendaklah is related to muamalah and akidah. Prohibition adverbial modality marked with janganlah is connected to muamalah, akidah, and ibadah. There are six character values stated by Kepmendiknas (2010), which are religiousness, tolerance, responsibility, honesty, peace loving, and discipline. In addition, five character values are also found, which are politeness, wisdom, justice, leadership, and love. Thus, this research offers five additional values that have not been stated by Kepmendiknas (2010).

\section{References}

Astati, Dwi Puasa. (2013). Analysis of linguistic modesty in the translation text of alquran surah al-Ishra. FKIP Progdi Bahasa Indonesia, Muhammadiyah University of Surakarta. Retrieved from http://eprints.ums. ac.id/25169.
Az-Zuhali, Wahbah. (2010). Fiqih Islam wa adillatuhu: introduction to fiqh science, figures of fiqh school of intellect, intention, thaharah, and prayer. (Abdul Hayyie al-Kattani, et. al). Jakarta: Gema Insani.

Chaer, Abdul. (2015). Practical grammar of indonesian language. Jakarta: Rineka Cipta.

Cristiana, Davidescu. (2008). Russian verba adverbia and disclosure of its meanings in bahasa Indonesia. Sosiohumaniora, 10(1), 13-23. Retrieved from http://conference.unsri.ac.id/index.php/SNBI/article/vie w/519.

Fikri, Arief Abdillah. (2014). Analysis of conjunctions on the translation of surat an-nisa. FKIP, Progdi Bahasa Indonesia, Uniersitas Muhammadiyah Surakarta. Retrieved from http://eprints.ums.ac.id/31091/.

Katsir, Imam Ibnu. (2016). Tafseer ibn kathir: introduction to the science of tafsir. (Arif Rahman Hakim, et al). Sukoharjo: Insan Kamil.

Kemendiknas. (2010). Pengembangan pendidikan budaya dan karakter bangsa: Pedoman sekolah. Jakarta: Badan Penelitian dan Pengembangan Pusat Pusat Kurikulum.

Khasanah, Niswatul. (2015). Modality souda, souda, and $\sim$ rashii on japanese sentence. FIB, Prodi S1 of Japanese Literature, Dipenogoro University. Retrieved from http://eprints.undip.ac.id/45481/1/skripsi_keseluruhan_se mntara.pdf.

Kiss (ed.), Katalin E'. (2011). Adverbs and adverbial adjuncts at the interfaces (Interface Explorations 20). Berlin: Mouton de Gruyter, 2009. J. Linguistics, 47, pp. viii+377. doi:10.1017/S0022226710000435 f Cambridge University Press.

Kridalaksana, Harimurti. (2005). Word class in bahasa Indonesia. Jakarta: Gramedia.

Mahayana, Maman S. (2008). Creative Indonesia. Jakarta: Penaku.

Markhamah and Atiqa Sabardila. (2010). Alignment of functions, categories and roles in the Alquran translation text. Competence Grant Research Report Financed by Higher Education through Institute of Research and Community Service, Muhammadiyah University of Surakarta.

Markhamah, Abdul Ngalim, Muhammad Muinuddinilaah Basri. (2012). Development of textual material and syntax based textual lessons on alquran translation. Grant Research Report Graduate Teams University of Muhammadiyah Surakarta. Financed by Higher Education Year II. Retrieved from https://publikasiilmiah.ums.ac.id/handle/11617/2460?sho $\underline{w}=$ full.

Markhamah, Abdul Ngalim, M. Muinuddinillah Basri, Atiqa Sabardila (2012). Replacement transformation on the translation of the Quranic text containing ethical language. Linguistic and Literary Studies, 24(2), 139151. Retrieved from https://publikasiilmiah. ums.ac.id/handle/11617/35.

Markhamah. (2003). Gender in translation quranic verses on men and women, Profetika. December 2003. 
Muslich, Mansur. (2008). Bahasa Indonesia form: a descriptive toward directions. East Jakarta: Earth Script.

Ramadhana, Anisaa Faudillah. (2014). The lingual unit containing the third persona pronomina on the translation of the alquranic text of ethical language. Postgraduate of Muhammadiyah University of Surakarta. Retrieved

from http://eprints.ums.ac.id/32546/15/02.\%20JURNAL\%20 PUBLIKASI.pdf.

Ramlan, M. (1991). Indonesian grammar classification. Yogyakarta: Andi Offset.

Rosdawita. (2012). Adverbia minangkabau language modalities. Pen. 2(2), 85-98. Retrieved from https://onlinejournal.unja.ac.id/index.php/pena/article/view/1435.

Shofiyuddin. (2013). Sentence transformation transformation on translation text of alquran containing ethical language. Postgraduate of Muhammadiyah Surakata University. $\quad$ Retrieved from http://eprints.ums.ac.id/24337/16/08_naskah_publikasi.p df.

Sabardila, Atiqa; Sangidu; Hindun, Andi Haris Prabawa; Adyana Sunanda. (2003). Etika berbahasa dalam Islam: kajian secara sosiolinguistik. Laporan Penelitian Hibah Pekerti (Tahun I). Dibiayai DP2M Dikti, melalui LPPM, Universitas Muhammadiyah Surakarta.

Ramli. T (2003). Pendidikan karakter. Bandung: Angkasa.

Sholichah, Eri. (2014). Analysis of synthetic lexical cohesion on translation text of alquran surah An-nahl. FKIP, Prodi Indonesian Literature Language, University of Muhammadiyah Surakarta. Retrieved from http://eprints.ums.ac.id/28562/17/NASKAH_PUBLIKA SI.pdf.

Sugono, Dendy. (2012). Dictionary of bahasa Indonesia language center. Jakarta: Gramedia.

Tarmizi, Erwandi. (2013). Contemporary hidden treasures. Bogor: Berkat Mulia Insani.

Widjono. (2012). Bahasa Indonesia personality development course in higher education. Jakarta: Grasindo.

Wirjosoedarmo, Soekono. (1984). Grammar of Indonesian language. Surabaya: Sinar Wijaya.

$\mathrm{Xu}$, Yuting and Yuhui Liu. (2012). The use of adverbial conjuncts of the chinese EFL learnes and native speakers-corpus-based study. Theory and Practice in Language Studies, 2(11), 2316-2321. Retrieved from https://search.proquest.com/openview/950f42bcc288c6c 0ffce $71 \mathrm{~b} 78 \mathrm{e} 20 \mathrm{~b} 600 / 1$ ?pq-

origsite $=$ gscholar\&cbl $=2026476$. 